\title{
Iron(II)-Catalyzed Hydroamination of Isocyanates
}

\author{
Amy J. South, ${ }^{\dagger}$ Ana M. Geer, ${ }^{*}, \dagger, \S\left(\right.$ Laurence J. Taylor, $^{\dagger}$ Helen R. Sharpe, ${ }^{\dagger}$ William Lewis, ${ }^{\ddagger}$ \\ Alexander J. Blake, ${ }^{\dagger}$ and Deborah L. Kays*, ${ }^{*}$ 이 \\ ${ }^{\dagger}$ School of Chemistry, University of Nottingham, University Park, Nottingham NG7 2RD, United Kingdom \\ ${ }^{\ddagger}$ School of Chemistry, The University of Sydney, F11 Eastern Ave, Sydney, New South Wales 2006, Australia
}

pubs.acs.org/Organometallics

\section{Supporting Information}

ABSTRACT: A two-coordinate Fe(II) $m$-terphenyl complex acts as a precatalyst for the hydroamination of isocyanates, affording urea and biuret derivatives, with product selectivity accomplished via modification of the reaction conditions. Using a more nucleophilic amine facilitates the insertion of up to four isocyanates into the $\mathrm{N}-\mathrm{H}$ bond, affording triuret and tetrauret derivatives.

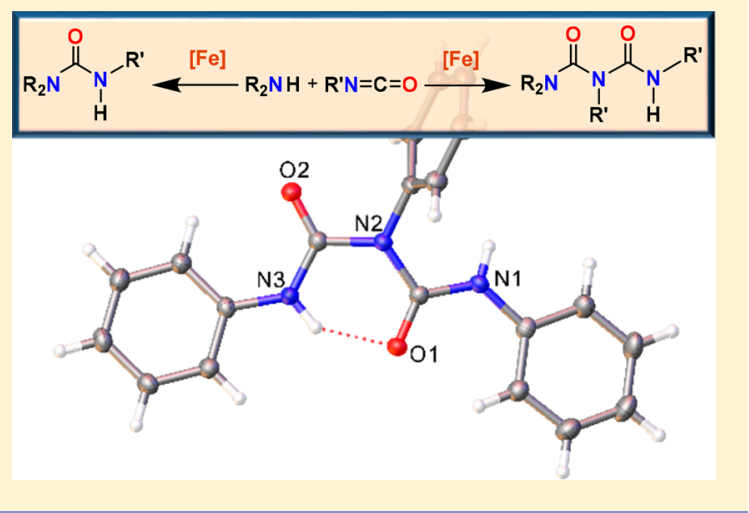

$\mathrm{U}$ rea derivatives are essential in a wide range of biological systems $^{1}$ and are fundamental building blocks in the chemical industry and academia with a wide range of applications in pharmaceuticals, ${ }^{2}$ agriculture, ${ }^{3}$ material, ${ }^{4}$ supramolecular, ${ }^{5}$ and synthetic chemistry. ${ }^{6}$ Despite their importance, there are few methods for the synthesis of urea derivatives. Most synthetic routes require the use of expensive noble metal catalysts, for example, via oxidative catalytic carbonylation reactions of amines, ${ }^{7}$ catalytic reduction of nitro compounds with carbon monoxide, ${ }^{8}$ and the cross-coupling of aryl chlorides with sodium cyanate, ${ }^{9}$ or they include stoichiometric amounts of other reagents. ${ }^{10}$ More recently, ureas have been synthesized through the coupling of silylamines and carbon dioxide using an indium precatalyst ${ }^{11}$ and an iron-catalyzed dehydrogenative coupling of methanol and amines. ${ }^{12}$

Hydroamination is an atom-economical alternative to the above routes, in which an $\mathrm{N}-\mathrm{H}$ bond is added across an unsaturated organic bond, affording $\mathrm{C}-\mathrm{N}$ bonds without the need for dehydrating/activating agents. ${ }^{13}$ The catalytic hydroamination of alkenes, alkynes, and carbodiimides to form $\mathrm{C}-\mathrm{N}$ bonds has been widely studied. ${ }^{14}$ However, there are few reported examples for the catalytic hydroamination of isocyanates leading to urea derivatives; with examples limited to group $2,{ }^{15}$ titanium, ${ }^{16}$ zinc, $^{17}$ and actinide complexes. ${ }^{18}$ Although some hydroamination reactions of isocyanates can occur without a catalyst, these generally require long reaction times and high temperatures and are limited to nucleophilic amines. $^{19}$

The synthesis of biuret and triuret derivatives is especially challenging, as ureas are significantly less nucleophilic than secondary amines ${ }^{20}$ due to the electron-withdrawing effect of the carbonyl group. As a result, there are very few examples of these compounds being formed catalytically. Early studies report the synthesis of biurets from the pyrolysis of ureas or their catalytic formation from substituted ureas using organotin compounds. $^{21} \mathrm{~A}$ more recent study tested several catalysts such as $\mathrm{SOCl}_{2}$ and $\mathrm{ClSO}_{2} \mathrm{OH}$ for the transformation of urea to biuret. This method gave higher yields than the pyrolytic decomposition, although the synthesis required high temperatures $\left(145^{\circ} \mathrm{C}\right) .^{22}$ To our knowledge, there are no reports of the direct transformation of secondary amines to biuret derivatives. The absence of direct catalytic routes is surprising considering the significance of molecules with multiple urea moieties, as such species have a high capacity for hydrogen bonding, which is valuable in the design of foldamers, ${ }^{23}$ selfassembly, ${ }^{24}$ and molecular recognition. ${ }^{25}$

We have previously reported the hydrophosphination of isocyanates mediated by low-coordinate $\mathrm{Fe}$ (II) precatalysts. ${ }^{26}$ We present here an expansion of this work, using the iron precatalyst $\left(2,6-\mathrm{Mes}_{2} \mathrm{C}_{6} \mathrm{H}_{3}\right)_{2} \mathrm{Fe}^{27}\left(\mathbf{1} ; \mathrm{Mes}=2,4,6-\mathrm{Me}_{3} \mathrm{C}_{6} \mathrm{H}_{2}\right)$ for the hydroamination of isocyanates to afford urea and biuret derivatives, the latter being achieved via a unique diinsertion reaction. Triuret and tetrauret compounds are obtained from more nucleophilic amines via unusual tri- and tetrainsertion pathways.

Initial efforts focused on the reaction between $\mathrm{Ph}_{2} \mathrm{NH}$ and PhNCO (Scheme 1), allowing for a direct comparison with the analogous hydrophosphination reaction with $\mathrm{Ph}_{2} \mathrm{PH}^{26}$ Monitoring the reaction between $\mathrm{Ph}_{2} \mathrm{NH}$ and $\mathrm{PhNCO}(1: 1$ substrate ratio, $\mathrm{C}_{6} \mathrm{D}_{6}, 25{ }^{\circ} \mathrm{C}, 5 \mathrm{~mol} \%$ 1) by ${ }^{1} \mathrm{H}$ NMR

Received: June 11, 2019

Published: October 7, 2019 
Scheme 1. Hydroamination of Isocyanates with $\mathrm{R}_{2} \mathrm{NH}$ Catalyzed by $1^{a}$

$$
\begin{array}{ll}
\mathrm{R}=\mathrm{Ph}, \mathrm{R}^{\prime}=\mathrm{Ph}(\mathbf{2 a}), 3,5-(\mathrm{OMe})_{2} \mathrm{C}_{6} \mathrm{H}_{3}(\mathbf{2 b}), & \mathrm{R}=\mathrm{Ph}, \mathrm{R}^{\prime}=\mathrm{Ph}(\mathbf{3 a}), 3,5-(\mathrm{OMe})_{2} \mathrm{C}_{6} \mathrm{H}_{3}(\mathbf{3 b}), \\
4-\mathrm{BrC}_{6} \mathrm{H}_{4}(\mathbf{3 c}) . \\
\mathrm{R}={ }^{\prime} \mathrm{Pr}, \mathrm{R}^{\prime}=\mathrm{Ph}(\mathbf{3 f}) .
\end{array}
$$

${ }^{a}$ Reaction conditions: (a) 5 mol \% $\mathbf{1} ; \mathrm{Ph}_{2} \mathrm{NH} / \mathrm{RNCO}(1: 1)$ in THF at $60{ }^{\circ} \mathrm{C}(2 \mathrm{a}-2 \mathrm{e})$. (b) $5 \mathrm{~mol} \% \mathrm{1} ; \mathrm{Ph}_{2} \mathrm{NH} / \mathrm{RNCO}$ ratio $(1: 5)$ in $\mathrm{C}_{6} \mathrm{D}_{6}$ at 25 or $60^{\circ} \mathrm{C}(3 \mathrm{a}-3 \mathrm{c})$ and ${ }^{i} \mathrm{Pr}_{2} \mathrm{NH} / \mathrm{PhNCO}(1: 2)$ in $\mathrm{C}_{6} \mathrm{D}_{6}$ at $25^{\circ} \mathrm{C}$ (3f).

spectroscopy revealed $93 \%$ conversion after $20 \mathrm{~h}$. Two products are obtained in a relative ratio of $88: 12$ (Table 1 , entry 1$)$ with the major product being urea $2 \mathrm{a}\left[\mathrm{Ph}_{2} \mathrm{NC}(=\right.$ $\mathrm{O}) \mathrm{N}(\mathrm{H}) \mathrm{Ph}]$ and the minor product being biuret $3 \mathrm{a}\left[\mathrm{Ph}_{2} \mathrm{NC}\right.$ $(=\mathrm{O}) \mathrm{N}(\mathrm{Ph}) \mathrm{C}(=\mathrm{O}) \mathrm{N}(\mathrm{H}) \mathrm{Ph}$. The presence of excess $\mathrm{PhNCO}$ increases the yield of $3 \mathrm{a}$, with a $\mathrm{Ph}_{2} \mathrm{NH} / \mathrm{PhNCO}$ ratio of $1: 2$ giving a $44 \%$ NMR yield, while a $1: 5$ ratio of $\mathrm{Ph}_{2} \mathrm{NH} / \mathrm{PhNCO}$ affords $3 \mathrm{a}$ as the major product $(71 \%$, Table 1 , entries 2 and 3 ) with excellent conversions in both cases. At $60{ }^{\circ} \mathrm{C}$, the reaction time is reduced to $4 \mathrm{~h}$, and the selectivity for 3a increases (90\%, Table 1, entry 4). Control experiments between $\mathrm{Ph}_{2} \mathrm{NH}$ and isocyanates in the absence of 1 revealed either no hydroamination reaction or very low conversions in all cases (Table S1 and Supporting Information section S2.4).

Precatalyst 1 was found to be effective for a range of isocyanates, including both electron-rich and -poor species (Table 1, entries 5-10). When 4- $\mathrm{BrC}_{6} \mathrm{H}_{4} \mathrm{NCO}$ was used, the reaction was significantly slower at $25{ }^{\circ} \mathrm{C}$ (Table 1 , entry 8); however, full conversion was achieved after $4 \mathrm{~h}$ at $60{ }^{\circ} \mathrm{C}$ (Table 1, entry 9). As with $\mathrm{PhNCO}$, reactions with both 3,5$(\mathrm{MeO})_{2} \mathrm{C}_{6} \mathrm{H}_{3} \mathrm{NCO}$ and $4-\mathrm{BrC}_{6} \mathrm{H}_{4} \mathrm{NCO}$ in a $1: 5$ ratio of $\mathrm{Ph}_{2} \mathrm{NH} / \mathrm{R}^{\prime} \mathrm{NCO}$ showed excellent selectivity for diinsertion products $3 \mathbf{b}(100 \%)$ and $3 \mathbf{c}(98 \%)$, respectively (Table 1 , entries 7 and 10). For primary aliphatic isocyanate substrates, a competing cyclotrimerization of the isocyanate affording isocyanurates is observed. ${ }^{28}$ It is worth noting that when secondary and tertiary aliphatic isocyanates $\left(\mathrm{R}^{\prime}={ }^{i} \operatorname{Pr}\right.$ and $\left.{ }^{t} \mathrm{Bu}\right)$ are used the reaction exclusively affords monoinsertion products $\mathbf{2 d}$ and $\mathbf{2 e}$, respectively (Table 1 , entries 11 and 12). When reactions containing excess isocyanate were left over several days, cyclotrimerization of the unreacted isocyanates to isocyanurates was observed. This cyclotrimerization reaction has been previously reported to be catalyzed by Lewis bases, ${ }^{29}$ and it is therefore presumably catalyzed by either the $\mathrm{Ph}_{2} \mathrm{NH}$ substrate or the resulting urea products. Similar to the hydrophosphination of isocyanates with precatalyst $1,{ }^{26}$ changing the solvent from $\mathrm{C}_{6} \mathrm{D}_{6}$ to $\mathrm{THF}$ results in the exclusive formation of monoinsertion products $\mathbf{2 a - 2 c}$ (Scheme 1).

The hydroamination of aniline to afford urea $\mathbf{2 g}$ occurs without a catalyst (Table S1), but the presence of $\mathbf{1}$ affords biuret $\mathbf{3 g}$ (Scheme 2 and Supporting Information section S3.1)

Scheme 2. Hydroamination of Phenyl Isocyanate with $\mathrm{PhNH}_{2}$ Catalyzed by 1 Leads to the formation of $2 \mathrm{~g}$ and $3 \mathrm{~g}^{a}$

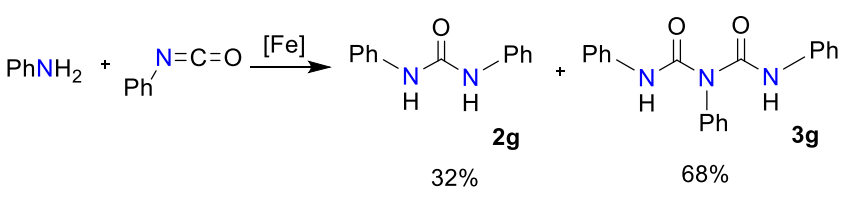

${ }^{a}$ Reaction conditions: 5 mol \% 1, 1:5 $\mathrm{PhNH}_{2} / \mathrm{PhNCO}$ ratio in $\mathrm{C}_{6} \mathrm{D}_{6}$ at $25{ }^{\circ} \mathrm{C}$.

as the major product. The molecular structure of $\mathbf{3 g}$ was determined by X-ray crystallography (Figures 1 and S23) and features both intermolecular and intramolecular hydrogen bonds. $\mathrm{O} 2$ features a $\mathrm{H}$-bond to $\mathrm{H} 1[\mathrm{O} \cdots \mathrm{N} 2.8809(13) \AA ̊ \mathrm{O}, \mathrm{O}$ $\mathrm{H} 2.054(17) \AA]$ in a neighboring molecule (Figures 1 and $\mathrm{S} 23$ ), while the amide oxygen $\mathrm{O} 1$ displays two intramolecular $\mathrm{H}$-bonds to $\mathrm{H} 2$ [O $\cdots \mathrm{C} 2.8208(16) \AA$, $\mathrm{O} \cdots \mathrm{H} 2.2134(10) \AA]$ and $\mathrm{H} 3[\mathrm{O} \cdots \mathrm{N} 2.5881(14) \AA, \mathrm{O} \cdots \mathrm{H} 1.831(18) \AA]$.

The catalysis was conducted in the presence of different additives (Table 2). In contrast to the hydrophosphination of isocyanates by the same precatalyst, $\mathbf{1},{ }^{26}$ addition of a weak acid $\left(\mathrm{NEt}_{3} \cdot \mathrm{HCl}\right)$ has only a minor effect on the product

\begin{tabular}{|c|c|c|c|c|c|c|c|}
\hline entry & $\mathrm{R}_{2} \mathrm{NH}$ & $\mathrm{R}^{\prime} \mathrm{NCO}$ & $\mathrm{R}_{2} \mathrm{NH} / \mathrm{R}^{\prime} \mathrm{NCO}$ & $T\left({ }^{\circ} \mathrm{C}\right)$ & $t(\mathrm{~h})$ & conv. $(\%)^{b}$ & $2 / 3(\%)^{b}$ \\
\hline 1 & $\mathrm{Ph}$ & $\mathrm{Ph}$ & $1: 1$ & 25 & 20 & 93 & $88 / 12$ \\
\hline 2 & $\mathrm{Ph}$ & $\mathrm{Ph}$ & $1: 2$ & 25 & 20 & 100 & $56 / 44$ \\
\hline 3 & $\mathrm{Ph}$ & $\mathrm{Ph}$ & $1: 5$ & 25 & 20 & 100 & $29 / 71$ \\
\hline 4 & $\mathrm{Ph}$ & $\mathrm{Ph}$ & $1: 5$ & 60 & 4 & 100 & $10 / 90$ \\
\hline 5 & $\mathrm{Ph}$ & $(\mathrm{MeO})_{2} \mathrm{C}_{6} \mathrm{H}_{3}$ & $1: 1$ & 25 & 24 & 92 & $100 / 0$ \\
\hline 6 & $\mathrm{Ph}$ & $(\mathrm{MeO})_{2} \mathrm{C}_{6} \mathrm{H}_{3}$ & $1: 2$ & 60 & 17 & 100 & $41 / 59$ \\
\hline 7 & $\mathrm{Ph}$ & $(\mathrm{MeO})_{2} \mathrm{C}_{6} \mathrm{H}_{3}$ & $1: 5$ & 25 & 2 & 80 & $0 / 100$ \\
\hline 8 & $\mathrm{Ph}$ & $4-\mathrm{BrC}_{6} \mathrm{H}_{4}$ & $1: 1$ & 25 & 96 & 80 & $100 / 0$ \\
\hline 9 & $\mathrm{Ph}$ & 4- $\mathrm{BrC}_{6} \mathrm{H}_{4}$ & $1: 2$ & 60 & 4 & 100 & $57 / 43$ \\
\hline 10 & $\mathrm{Ph}$ & 4- $\mathrm{BrC}_{6} \mathrm{H}_{4}$ & $1: 5$ & 60 & 4 & 100 & $2 / 98$ \\
\hline 11 & $\mathrm{Ph}$ & ${ }^{i} \operatorname{Pr}$ & $1: 1$ & 60 & 4 & 96 & $100 / 0$ \\
\hline 12 & $\mathrm{Ph}$ & ${ }^{t} \mathrm{Bu}$ & $1: 1$ & 25 & 3 & 92 & $100 / 0$ \\
\hline 13 & ${ }^{i} \operatorname{Pr}$ & $\mathrm{Ph}$ & $1: 2$ & 25 & 0.1 & 100 & $0 / 87 / 13^{c}$ \\
\hline 14 & ${ }^{i} \operatorname{Pr}$ & $\mathrm{Ph}$ & $1: 5$ & 25 & 0.1 & 100 & $0 / 25 / 54^{c} / 21^{d}$ \\
\hline
\end{tabular}
distribution (Table 2, entry 1 ).

In order to determine whether the catalysis was heterogeneous or homogeneous, poisoning experiments ${ }^{30}$ were carried

Table 1. Catalytic Hydroamination of Isocyanates Mediated by $\mathbf{1}^{a}$

${ }^{a}$ Reaction conditions: $10 \mathrm{mg}$ of 1 (5 mol \%), $0.6 \mathrm{~mL}$ of $\mathrm{C}_{6} \mathrm{D}_{6} \cdot{ }^{b}$ Determined by ${ }^{1} \mathrm{H}$ NMR spectroscopy using either trimethoxybenzene or TMS as an internal standard. ${ }^{c}$ Triinsertion product $(\mathbf{4 f}) .{ }^{d}$ Tetrainsertion product $(\mathbf{5 f})$. 


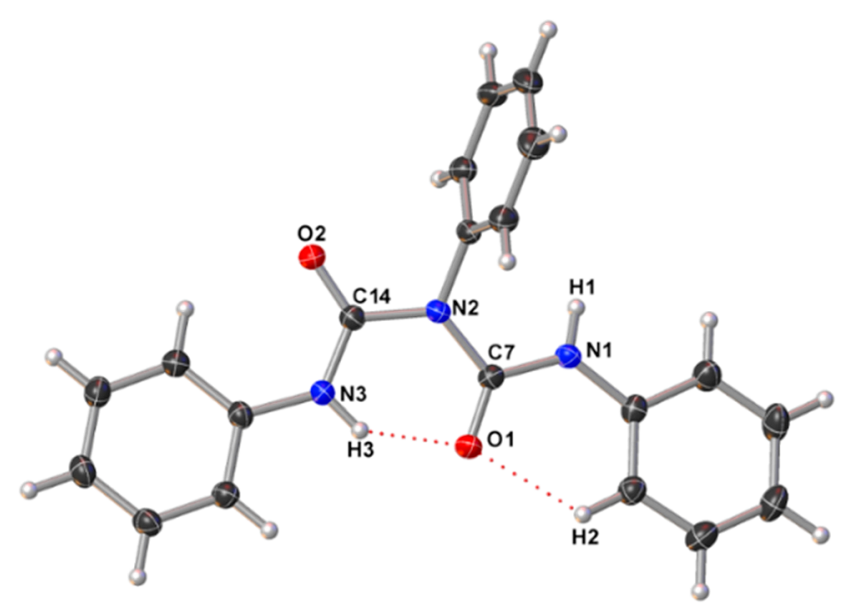

Figure 1. Molecular structure of $3 \mathrm{~g}$ with anisotropic displacement ellipsoids set at $50 \%$ probability. Selected bond lengths $(\AA)$ and angles (deg):N1-C7 1.3534(16), C7-N2 1.4159(15), C7-O1 1.2268(15), N2-C14 1.4260(16), C14-O2 1.2199(15), C14-N3 1.3474(16),

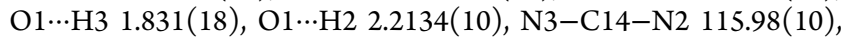
N2-C7-N1 114.15(10), C7-N2-C14 124.20(10).

Table 2. Catalytic Hydroamination of Isocyanates Mediated by 1 in the Presence of Additives ${ }^{a}$

\begin{tabular}{|c|c|c|c|c|c|c|c|}
\hline entry & $\mathrm{R}_{2} \mathrm{NH}$ & $\mathrm{R}^{\prime} \mathrm{NCO}$ & additive & $\begin{array}{c}T \\
\left({ }^{\circ} \mathrm{C}\right)\end{array}$ & $\begin{array}{c}t \\
(\mathrm{~h})\end{array}$ & $\begin{array}{l}\text { conv. } \\
(\%)^{b}\end{array}$ & $2 / 3(\%)^{b}$ \\
\hline 1 & $\mathrm{Ph}$ & $\mathrm{Ph}$ & $\mathrm{NEt}_{3} \cdot \mathrm{HCl}$ & 25 & 16 & 83 & $80 / 20$ \\
\hline 2 & $\mathrm{Ph}$ & $\mathrm{Ph}$ & $\mathrm{Hg}$ & 25 & 20 & 85 & $90 / 10$ \\
\hline 3 & $\mathrm{Ph}$ & ${ }^{t} \mathrm{Bu}$ & $\mathrm{CS}_{2}$ & 25 & 5 & 90 & $100 / 0$ \\
\hline 4 & $\mathrm{Ph}$ & ${ }^{t} \mathrm{Bu}$ & $\mathrm{PPh}_{3}$ & 40 & 2 & 90 & $100 / 0$ \\
\hline 5 & $\mathrm{Ph}$ & ${ }^{t} \mathrm{Bu}$ & $\mathrm{PPhMe}_{2}$ & 25 & 3 & 93 & $100 / 0$ \\
\hline
\end{tabular}

${ }^{a}$ Reaction conditions: $10 \mathrm{mg}$ of $\mathbf{1}$ (5 mol \%), $0.6 \mathrm{~mL}$ of $\mathrm{C}_{6} \mathrm{D}_{6}, 1: 1$ $\mathrm{R}_{2} \mathrm{NH} / \mathrm{R}^{\prime} \mathrm{NCO} .{ }^{b}$ Determined by ${ }^{1} \mathrm{H}$ NMR spectroscopy.

out using $\mathrm{Hg}(0)^{31}$ as well as $\mathrm{CS}_{2}, \mathrm{PPh}_{3}$, and $\mathrm{PPhMe}_{2} \cdot{ }^{32}$ In all cases, the reaction reached conversions similar to those without the additive, which suggests that the catalysis is proceeding through a homogeneous pathway (Table 2, entry $2-5)$. Moreover, no metal precipitate or darkening of the solutions was observed during the reaction, lending further support for a homogeneous mechanism. The catalysis was also performed in the presence of cumene, which can act as a radical trap. ${ }^{33}$ This did not inhibit the catalysis, suggesting that the reaction does not proceed via a radical mechanism.

A stoichiometric reaction between $1, \mathrm{Ph}_{2} \mathrm{NH}$, and $\mathrm{PhNCO}$ resulted in a color change from bright to pale yellow. In the ${ }^{1} \mathrm{H}$ NMR spectrum, the paramagnetically shifted peaks for 1 were no longer present, and new peaks were observed (Supporting Information section S7.1), indicating that $\mathbf{1}$ had transformed into a new paramagnetic species, possibly the active catalyst. This change is not observed when either $\mathrm{Ph}_{2} \mathrm{NH}$ or $\mathrm{PhNCO}$ alone is added to 1 . This stoichiometric reaction was also analyzed by UV/vis spectroscopy, mass spectrometry, and infrared spectroscopy. UV/vis spectroscopy revealed no significant change compared to the spectrum of precatalyst $1,{ }^{27}$ likely because the UV/vis transitions are dominated by the aromatic terphenyl ligands (Supporting Information section S7.2). Mass spectrometry of the reaction mixture showed the presence of diphenylamine and protonated terphenyl ligand (ArH species are common decomposition artifacts of the EI mass spectrometry measurements of these transition metal terphenyl complexes due to their high air- and moisturesensitivity), but no iron-containing products were identified (Supporting Information section S7.3). Infrared spectroscopy of the stoichiometric reaction in benzene revealed complete consumption of the substrates, with the disappearance of the characteristic $\mathrm{N}-\mathrm{H}$ and $\mathrm{N}=\mathrm{C}=\mathrm{O}$ stretching bands (Supporting Information section S7.4 and Figure S22). However, the lack of bands between $1600-1700 \mathrm{~cm}^{-1}$ and $3200-3500 \mathrm{~cm}^{-1}$ indicate that the stoichiometric reaction has not formed urea product 2 a. We therefore conclude that this reaction affords some unknown species, possibly the active catalyst, and that this does not contain any $\mathrm{N}-\mathrm{H}$ or $\mathrm{C}=\mathrm{O}$ functionalities.

Stoichiometric reactions with $\mathbf{1}$, aniline, and $\mathrm{PhNCO}$ again resulted in transformation of $\mathbf{1}$ into a new paramagnetic species (Supporting Information section S7.1). It is conceivable that the $\mathrm{Fe}(\mathrm{II})$ center will behave as a Lewis acid, similar to other low-coordinate transition metal aryl precatalysts. ${ }^{14 f, 26,28,34}$ Deprotonation of the amine by the terphenyl ligand to afford an iron amide was discounted, as formation of the free ligand is not observed by ${ }^{1} \mathrm{H}$ NMR spectroscopy in either the stoichiometric or catalytic reactions even when an excess of amine is used.

Kinetic experiments were undertaken to investigate the mechanism of this reaction (Supporting Information section S6). The reaction between $\mathrm{Ph}_{2} \mathrm{NH}$ and ${ }^{t} \mathrm{BuNCO}$ in the presence of 1 was chosen, as it cleanly affords a single product (2d), and the ${ }^{t} \mathrm{Bu}$ group gives clear distinct singlets for both product and reagent in the ${ }^{1} \mathrm{H}$ NMR spectrum. Three samples were prepared with an equimolar amount of $\mathrm{Ph}_{2} \mathrm{NH},{ }^{t} \mathrm{BuNCO}$, trimethoxybenzene, and $5 \mathrm{~mol} \%$ of $\mathbf{1}$. After monitoring the reaction for each of these 3 samples by ${ }^{1} \mathrm{H}$ NMR spectroscopy, the data showed poor reproducibility, with rate versus $\left[{ }^{t} \mathrm{BuNCO}\right]$ plots giving a different curve for each run (Figure S16). In one of these kinetic runs, a sigmoidal curve was observed in the plot of [ $\left.{ }^{t} \mathrm{BuNCO}\right]$ versus time (Figure S15). This suggests the reaction has an activation step, likely corresponding to the conversion of precatalyst $\mathbf{1}$ to the active species.

The inconsistency in the observed rates may be due to differences in the amount of active species generated in the time between sample preparation and transfer to the NMR spectrometer. Although samples were frozen at $-78^{\circ} \mathrm{C}$ as soon as possible after preparation and remained frozen until they could be measured, it was not possible to prevent this initiation reaction occurring to different degrees in each sample. As such, we could not obtain meaningful kinetic data via this method.

The substrate scope has been broadened to a more nucleophilic amine, ${ }^{i} \mathrm{Pr}_{2} \mathrm{NH}$ (Scheme 3). In the absence of a catalyst, the reaction with $\mathrm{PhNCO}$ affords urea $2 \mathrm{f}$ at $25^{\circ} \mathrm{C}$ (Scheme 3, Table S1). However, in the presence of $5 \mathrm{~mol} \% \mathbf{1}$, $\mathbf{2 f}$ is not observed. Instead, diinsertion product $3 \mathbf{f}$ is the major product (Table 1, entry 13), with small amounts of triinsertion product $4 \mathbf{f}$. When the ratio of ${ }^{i} \mathrm{Pr}_{2} \mathrm{NH} / \mathrm{PhNCO}$ ratio is increased to $1: 5$ the tetrainsertion product $(\mathbf{5 f})$ is also observed (Table 1, entry 14). These products were identified by ${ }^{1} \mathrm{H},{ }^{13} \mathrm{C}\left\{{ }^{1} \mathrm{H}\right\}$ and DOSY NMR spectroscopy and mass spectrometry (Figure S13 and Table S2). When the reaction is performed using the urea ${ }^{i} \operatorname{Pr}_{2} \mathrm{NC}(\mathrm{O}) \mathrm{NHPh}$ (2f) as the substrate, complete conversion to the polyinsertion products is accomplished in $10 \mathrm{~min}$ at $25{ }^{\circ} \mathrm{C}(5 \mathrm{~mol} \%$ of $\mathbf{1}$, ${ }^{i} \mathrm{Pr}_{2} \mathrm{NC}(\mathrm{O}) \mathrm{NHPh} / \mathrm{PhNCO}$ ratio of $\left.1: 4\right)$, with a similar product distribution. Although $\mathbf{4 f}$ and $\mathbf{5 f}$ are obtained as mixtures (3f $25 \%$, 4 f $54 \%$, and 5 f $21 \%$ ), it should be noted that 
Scheme 3. Hydroamination of $\mathrm{PhNCO}$ with ${ }^{i} \mathrm{Pr}_{2} \mathrm{NH}^{a}$

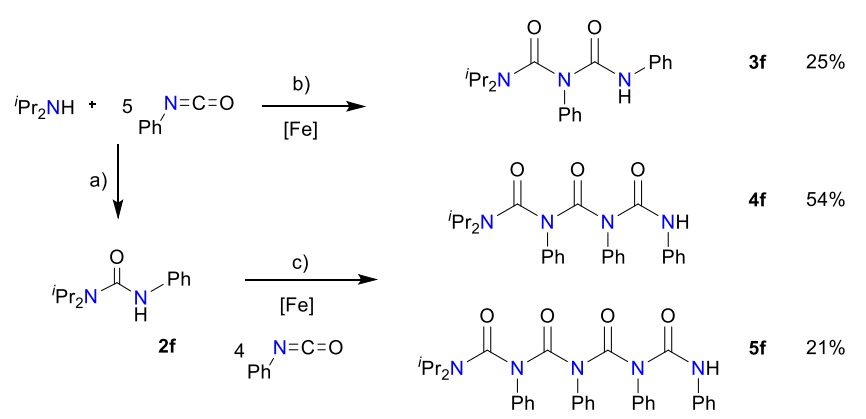

${ }^{a}$ Reaction conditions: (a) without catalyst, ratio ${ }^{i} \mathrm{Pr}_{2} \mathrm{NH} / \mathrm{PhNCO}$ 1:1, $1 \mathrm{~h}$ at $25{ }^{\circ} \mathrm{C}$ in $\mathrm{C}_{6} \mathrm{D}_{6}$. (b) $5 \mathrm{~mol} \% \mathrm{1}$, ratio ${ }^{i} \mathrm{Pr}_{2} \mathrm{NH} / \mathrm{PhNCO} 1: 5,10$ min at $25{ }^{\circ} \mathrm{C}$ in $\mathrm{C}_{6} \mathrm{D}_{6}$. (c) $5 \mathrm{~mol} \% 1$, ratio ${ }^{i} \mathrm{Pr}_{2} \mathrm{NC}(=\mathrm{O}) \mathrm{NH}(\mathrm{Ph}) /$ PhNCO 1:4, 10 min at $25{ }^{\circ} \mathrm{C}$ in $\mathrm{C}_{6} \mathrm{D}_{6}$.

there are very few reported synthetic routes to these compounds in the literature. ${ }^{35}$ Given the importance of species with multiple amide functionalities in natural products, ${ }^{36}$ drugs, ${ }^{37}$ and polymers, ${ }^{38}$ the synthesis of these molecules under such mild conditions is promising for future development.

In conclusion, the two-coordinate $\mathrm{Fe}$ (II) complex $(2,6-$ $\left.\mathrm{Mes}_{2} \mathrm{C}_{6} \mathrm{H}_{3}\right)_{2} \mathrm{Fe}$ is an effective precatalyst for the mono- and diinsertion of isocyanates into $\mathrm{N}-\mathrm{H}$ bonds in primary and secondary amines. Modification of the reaction conditions can alter the product distribution, allowing for the selective formation of ureas or enhanced selectivity of biuret products. Using a more nucleophilic amine produces triuret and tetrauret derivatives which are difficult to obtain by other synthetic routes.

Experiments to understand this catalytic process have indicated that it is likely complex in nature, but they have shown that a new paramagnetic active species is formed during the reaction and have allowed us to rule out activation mechanisms such as amine deprotonation. Future experiments to compare the behavior of $\mathbf{1}$ against other two-coordinate iron complexes may help shed further light on this mechanism.

\section{ASSOCIATED CONTENT}

\section{S Supporting Information}

The Supporting Information is available free of charge on the ACS Publications website at DOI: 10.1021/acs.organomet.9b00393.

Experimental procedures, NMR spectra, and crystallographic data (PDF)

\section{Accession Codes}

CCDC 1850900 contains the supplementary crystallographic data for this paper. These data can be obtained free of charge via www.ccdc.cam.ac.uk/data_request/cif, or by emailing data_request@ccdc.cam.ac.uk, or by contacting The Cambridge Crystallographic Data Centre, 12 Union Road, Cambridge CB2 1EZ, UK; fax: +44 1223336033.

\section{AUTHOR INFORMATION}

\section{Corresponding Authors}

*E-mail: ag3kj@virginia.edu (A.M.G.).

*E-mail: Deborah.Kays@nottingham.ac.uk (D.L.K.).

\section{ORCID $\odot$}

Ana M. Geer: 0000-0003-1115-6759
Alexander J. Blake: 0000-0003-2257-8332

Deborah L. Kays: 0000-0002-4616-6001

\section{Present Address}

${ }^{\S}$ A.M.G.: Department of Chemistry, University of Virginia, Charlottesville, VA 22904, USA.

\section{Notes}

The authors declare no competing financial interest.

\section{ACKNOWLEDGMENTS}

This work was supported by the Engineering and Physical Sciences Research Council [grant number EP/R004064/1]; The Leverhulme Trust [grant number RPG-2014-317]; and the University of Nottingham. We thank Dr Mick Cooper (University of Nottingham) for mass spectrometry and Dr Huw Williams (University of Nottingham) for helpful NMR spectroscopic discussions, and assistance with DOSY NMR spectroscopy.

\section{REFERENCES}

(1) Liu, W.; Tang, Y.; Guo, Y.; Sun, B.; Zhu, H.; Xiao, Y.; Dong, D.; Yang, C. Synthesis, characterization and bioactivity determination of ferrocenyl urea derivatives. Appl. Organomet. Chem. 2012, 26, 189193.

(2) (a) Kim, I.-H.; Tsai, H.-J.; Nishi, K.; Kasagami, T.; Morisseau, C.; Hammock, B. D. 1,3-Disubstituted Ureas Functionalized with Ether Groups are Potent Inhibitors of the Soluble Epoxide Hydrolase with Improved Pharmacokinetic Properties. J. Med. Chem. 2007, 50, 5217-5226. (b) McMorris, T. C.; Chimmani, R.; Alisala, K.; Staake, M. D.; Banda, G.; Kelner, M. J. Structure-activity studies of urea, carbamate, and sulfonamide derivatives of acylfulvene. J. Med. Chem. 2010, 53, 1109-16. (c) Ballinger, E.; Mosior, J.; Hartman, T.; BurnsHuang, K.; Gold, B.; Morris, R.; Goullieux, L.; Blanc, I.; Vaubourgeix, J.; Lagrange, S.; Fraisse, L.; Sans, S.; Couturier, C.; Bacqué, E.; Rhee, K.; Scarry, S. M.; Aubé, J.; Yang, G.; Ouerfelli, O.; Schnappinger, D.; Ioerger, T. R.; Engelhart, C. A.; McConnell, J. A.; McAulay, K.; Fay, A.; Roubert, C.; Sacchettini, J.; Nathan, C. Opposing reactions in coenzyme A metabolism sensitize Mycobacterium tuberculosis to enzyme inhibition. Science 2019, 363, No. eaau8959.

(3) Guan, A.; Liu, C.; Yang, X.; Dekeyser, M. Application of the intermediate derivatization approach in agrochemical discovery. Chem. Rev. 2014, 114, 7079-107.

(4) Lin, B.; Waymouth, R. M. Urea Anions: Simple, Fast, and Selective Catalysts for Ring-Opening Polymerizations. J. Am. Chem. Soc. 2017, 139, 1645-1652.

(5) Dawn, S.; Salpage, S. R.; Koscher, B. A.; Bick, A.; Wibowo, A. C.; Pellechia, P. J.; Shimizu, L. S. Applications of a bis-urea phenylethynylene self-assembled nanoreactor for $[2+2]$ photodimerizations. J. Phys. Chem. A 2014, 118, 10563-74.

(6) Froidevaux, V.; Negrell, C.; Caillol, S.; Pascault, J. P.; Boutevin, B. Biobased Amines: From Synthesis to Polymers; Present and Future. Chem. Rev. 2016, 116, 14181-14224.

(7) (a) Krishnakumar, V.; Chatterjee, B.; Gunanathan, C. Ruthenium-Catalyzed Urea Synthesis by N-H Activation of Amines. Inorg. Chem. 2017, 56, 7278-7284. (b) Zhao, J.; Li, Z.; Yan, S.; Xu, S.; Wang, M. A.; Fu, B.; Zhang, Z. Pd/C Catalyzed Carbonylation of Azides in the Presence of Amines. Org. Lett. 2016, 18, 1736-9. (c) Park, J. H.; Yoon, J. C.; Chung, Y. K. Cobalt/Rhodium Heterobimetallic Nanoparticle-Catalyzed Oxidative Carbonylation of Amines in the Presence of Carbon Monoxide and Molecular Oxygen to Ureas. Adv. Synth. Catal. 2009, 351, 1233-1237.

(8) Gasperini, M.; Ragaini, F.; Remondini, C.; Caselli, A.; Cenini, S. The palladium-phenanthroline catalyzed carbonylation of nitroarenes to diarylureas: Effect of chloride and diphenylphosphinic acid. $J$. Organomet. Chem. 2005, 690, 4517-4529.

(9) Vinogradova, E. V.; Fors, B. P.; Buchwald, S. L. Palladiumcatalyzed cross-coupling of aryl chlorides and triflates with sodium 
cyanate: a practical synthesis of unsymmetrical ureas. J. Am. Chem. Soc. 2012, 134, 11132-5.

(10) Yagodkin, A.; Löschcke, K.; Weisell, J.; Azhayev, A. Straightforward carbamoylation of nucleophilic compounds employing organic azides, phosphines, and aqueous trialkylammonium hydrogen carbonate. Tetrahedron 2010, 66, 2210-2221.

(11) Xu, M.; Jupp, A. R.; Stephan, D. W. Stoichiometric Reactions of $\mathrm{CO}_{2}$ and Indium-Silylamides and Catalytic Synthesis of Ureas. Angew. Chem., Int. Ed. 2017, 56, 14277-14281.

(12) Lane, E. M.; Hazari, N.; Bernskoetter, W. H. Iron-catalyzed urea synthesis: dehydrogenative coupling of methanol and amines. Chem. Sci. 2018, 9, 4003-4008.

(13) (a) Patel, M.; Saunthwal, R. K.; Verma, A. K. Base-Mediated Hydroamination of Alkynes. Acc. Chem. Res. 2017, 50, 240-254. (b) Huang, L.; Arndt, M.; Goossen, K.; Heydt, H.; Goossen, L. J. Late transition metal-catalyzed hydroamination and hydroamidation. Chem. Rev. 2015, 115, 2596-2697.

(14) (a) Coman, S. M.; Parvulescu, V. I. Nonprecious Metals Catalyzing Hydroamination and C-N Coupling Reactions. Org. Process Res. Dev. 2015, 19, 1327-1355. (b) Bernoud, E.; Lepori, C.; Mellah, M.; Schulz, E.; Hannedouche, J. Recent advances in metal free- and late transition metal-catalysed hydroamination of unactivated alkenes. Catal. Sci. Technol. 2015, 5, 2017-2037. (c) Muller, T. E.; Hultzsch, K. C.; Yus, M.; Foubelo, F.; Tada, M. Hydroamination: Direct Addition of Amines to Alkenes and Alkynes. Chem. Rev. 2008, 108, 3795-3892. (d) De Tullio, M.; HernanGomez, A.; Livingstone, Z.; Clegg, W.; Kennedy, A. R.; Harrington, R. W.; Antinolo, A.; Martinez, A.; Carrillo-Hermosilla, F.; Hevia, E. Structural and Mechanistic Insights into s-Block Bimetallic Catalysis: Sodium Magnesiate-Catalyzed Guanylation of Amines. Chem. - Eur. J. 2016, 22, 17646-17656. (e) Komeyama, K.; Morimoto, T.; Takaki, $\mathrm{K}$. A simple and efficient iron-catalyzed intramolecular hydroamination of unactivated olefins. Angew. Chem., Int. Ed. 2006, 45, 2938-41. (f) Bernoud, E.; Oulie, P.; Guillot, R.; Mellah, M.; Hannedouche, J. Well-defined four-coordinate iron(II) complexes for intramolecular hydroamination of primary aliphatic alkenylamines. Angew. Chem., Int. Ed. 2014, 53, 4930-4. (g) Bezzenine-Lafollée, S.; Gil, R.; Prim, D.; Hannedouche, J. First-Row Late Transition Metals for Catalytic Alkene Hydrofunctionalisation: Recent Advances in C$\mathrm{N}, \mathrm{C}-\mathrm{O}$ and C-P Bond Formation. Molecules 2017, 22, 1901. (h) Zhu, K.; Shaver, M. P.; Thomas, S. P. Amine-bis(phenolate) Iron(III)Catalyzed Formal Hydroamination of Olefins. Chem. - Asian J. 2016, 11, 977-80.

(15) (a) Barrett, A. G.; Boorman, T. C.; Crimmin, M. R.; Hill, M. S.; Kociok-Kohn, G.; Procopiou, P. A. Heavier group 2 element-catalysed hydroamination of isocyanates. Chem. Commun. 2008, 5206-5208. (b) Hernan-Gomez, A.; Bradley, T. D.; Kennedy, A. R.; Livingstone, Z.; Robertson, S. D.; Hevia, E. Developing catalytic applications of cooperative bimetallics: competitive hydroamination/trimerization reactions of isocyanates catalysed by sodium magnesiates. Chem. Commun. 2013, 49, 8659-8661.

(16) (a) Bhattacharjee, J.; Das, S.; Kottalanka, R. K.; Panda, T. K. Hydroamination of carbodiimides, isocyanates, and isothiocyanates by a bis(phosphinoselenoic amide) supported titanium(iv) complex. Dalton Trans 2016, 45, 17824-17832. (b) Naktode, K.; Das, S.; Bhattacharjee, J.; Nayek, H. P.; Panda, T. K. Imidazolin-2-iminato Ligand-Supported Titanium Complexes as Catalysts for the Synthesis of Urea Derivatives. Inorg. Chem. 2016, 55, 1142-1153.

(17) Harinath, A.; Bano, K.; Ahmed, S.; Panda, T. K. 2Picolylamino(diphenylphosphinoselenoic)amide supported zinc complexes: Efficient catalyst for insertion of N-H bond into carbodiimides, isocyanates, and isothiocyanate. Phosphorus, Sulfur Silicon Relat. Elem. 2018, 193, 23-32.

(18) (a) Liu, H.; Fridman, N.; Tamm, M.; Eisen, M. S. Addition of E-H $(\mathrm{E}=\mathrm{N}, \mathrm{P}, \mathrm{C}, \mathrm{O}, \mathrm{S})$ Bonds to Heterocumulenes Catalyzed by Benzimidazolin-2-iminato Actinide Complexes. Organometallics 2017, 36, 3896-3903. (b) Karmel, I. S.; Tamm, M.; Eisen, M. S. Actinidemediated catalytic addition of $\mathrm{E}-\mathrm{H}$ bonds $(\mathrm{E}=\mathrm{N}, \mathrm{P}, \mathrm{S})$ to carbodiimides, isocyanates, and isothiocyanates. Angew. Chem., Int. Ed. 2015, 54, 12422-12425.

(19) Farkas, A.; Mills, G.A. Catalytic Effects in Isocyanate Reactions. Adv. Catal. 1962, 13, 393-446.

(20) Delebecq, E.; Pascault, J. P.; Boutevin, B.; Ganachaud, F. On the versatility of urethane/urea bonds: reversibility, blocked isocyanate, and non-isocyanate polyurethane. Chem. Rev. 2013, 113, $80-118$.

(21) Dyer, E.; Pinkerton, R. B. Kinetics of the Tin-Catalyzed Reactions of Phenyl Isocyanate with Ureas. J. Appl. Polym. Sci. 1965, 9, 1713-1729.

(22) Park, D. R.; Kim, H.; Jung, J. C.; Shin, M. S.; Han, S. J.; Song, I. K. Catalytic conversion of urea to biuret: A catalyst screening study. Korean J. Chem. Eng. 2009, 26, 990-993.

(23) (a) Hu, T.; Connor, A. L.; Miller, D. P.; Wang, X.; Pei, Q.; Liu, R.; He, L.; Zheng, C.; Zurek, E.; Lu, Z. L.; Gong, B. Helical Folding of Meta-Connected Aromatic Oligoureas. Org. Lett. 2017, 19, 26662669. (b) Hou, J. L.; Shao, X. B.; Chen, G. J.; Zhou, Y. X.; Jiang, X. K.; Li, Z. T. Hydrogen bonded oligohydrazide foldamers and their recognition for saccharides. J. Am. Chem. Soc. 2004, 126, 12386-94.

(24) (a) Moriuchi, T.; Tamura, T.; Hirao, T. Self-Assembly of Dipeptidyl Ureas: A New Class of Hydrogen-Bonded Molecular Duplexes. J. Am. Chem. Soc. 2002, 124, 9356-9357. (b) Kwiatkowski, A.; Grela, I.; Ośmiałowski, B. Conformational change in the association of a heterocyclic urea derivative forming two intramolecular hydrogen bonds in polar solvent. New J. Chem. 2017, 41, $1073-1081$.

(25) (a) Mroczynska, K.; Kaczorowska, M.; Kolehmainen, E.; Grubecki, I.; Pietrzak, M.; Osmialowski, B. Conformational equilibrium in supramolecular chemistry: Dibutyltriuret case. Beilstein J. Org. Chem. 2015, 11, 2105-16. (b) Zhang, D. W.; Zhao, X.; Hou, J. L.; Li, Z. T. Aromatic amide foldamers: structures, properties, and functions. Chem. Rev. 2012, 112, 5271-316.

(26) Sharpe, H. R.; Geer, A. M.; Lewis, W.; Blake, A. J.; Kays, D. L. Iron(II)-Catalyzed Hydrophosphination of Isocyanates. Angew. Chem., Int. Ed. 2017, 56, 4845-4848.

(27) Kays, D. L.; Cowley, A. R. Monomeric, two-coordinate Mn, Fe and $\mathrm{Co}$ (II) complexes featuring 2,6-(2,4,6-trimethylphenyl)phenyl ligands. Chem. Commun. 2007, 10, 1053-1055.

(28) Sharpe, H. R.; Geer, A. M.; Williams, H. E.; Blundell, T. J.; Lewis, W.; Blake, A. J.; Kays, D. L. Cyclotrimerisation of isocyanates catalysed by low-coordinate $\mathrm{Mn}(\mathrm{II})$ and $\mathrm{Fe}(\mathrm{II}) m$-terphenyl complexes. Chem. Commun. 2017, 53, 937-940.

(29) (a) Taguchi, Y.; Shibuya, I.; Yasumoto, M.; Tsuchiya, T.; Yonemoto, K. The Synthesis of Isocyanurates on the Trimerization of Isocyanates under high pressure. Bull. Chem. Soc. Jpn. 1990, 63, 3486-3489. (b) Kogon, I. C. New Reactions of Phenyl Isocyanate and Ethyl Alcohol. J. Am. Chem. Soc. 1956, 78, 4911-4914.

(30) (a) Crabtree, R. H. Resolving heterogeneity problems and impurity artifacts in operationally homogeneous transition metal catalysts. Chem. Rev. 2012, 112, 1536-1554. (b) Widegren, J. A.; Finke, R. G. A review of the problem of distinguishing true homogeneous catalysis from soluble or other metal-particle heterogeneous catalysis under reducing conditions. J. Mol. Catal. A: Chem. 2003, 198, 317-341.

(31) Even though mercury poisoning is not conclusive for iron because it does not form a stable amalgam, there are some examples where iron is successfully quenched using $\mathrm{Hg}(0)$ : (a) Li, Y.; Yu, S.; Wu, X.; Xiao, J.; Shen, W.; Dong, Z.; Gao, J. Iron Catalysed Asymmetric Hydrogenation of Ketones. J. Am. Chem. Soc. 2014, 136, 4031-4039. (b) Traff, A. M.; Janjetovic, M.; Ta, L.; Hilmersson, G. Selective C-F Activation: Substitution of Unactivated Alkyl Fluorides using $\mathrm{YbI}_{3}$. Angew. Chem., Int. Ed. 2013, 52, 12073-12076.

(32) Sonnenberg, J. F.; Morris, R. H. Distinguishing homogeneous from nanoparticle asymmetric iron catalysis. Catal. Sci. Technol. 2014, 4, 3426-3438.

(33) Gallagher, K. J.; Webster, R. L. Room temperature hydrophosphination using a simple iron salen pre-catalyst. Chem. Commun. 2014, 50, 12109-12111. 
(34) Lepori, C.; Hannedouche, J. First-Row Late Transition Metals for Catalytic (Formal) Hydroamination of Unactivated Alkenes. Synthesis 2017, 49, 1158-1167.

(35) (a) Richter, R. Die Addition aromatischer Isocyanate an Nsubstituierte Amidine. Chem. Ber. 1968, 101, 3002-3009. (b) Savel'ev, Y. V.; Khranovskii, V. A.; Veselov, V. Y.; Grekov, A. P.; Savel'eva, O. A. Specificity of the Reaction of 1,1-Dimethylhydrazine with Phenyl Isocyanate. Russ. J. Org. Chem. 2003, 39, 96-98. (c) Okamoto, Y.; Matsuda, M.; Nakano, T.; Yashima, E. Asymmetric polymerization of aromatic isocyanates with optically active anionic initiators. J. Polym. Sci., Part A: Polym. Chem. 1994, 32, 309-315.

(36) Dawlaty, J.; Zhang, X.; Fischbach, M. A.; Clardy, J. Dapdiamides, Tripeptide Antibiotics Formed by Unconventional Amide Ligases. J. Nat. Prod. 2010, 73, 441-446.

(37) (a) Verlinden, B. K.; Niemand, J.; Snyman, J.; Sharma, S. K.; Beattie, R. J.; Woster, P. M.; Birkholtz, L. M. Discovery of novel alkylated (bis)urea and (bis)thiourea polyamine analogues with potent antimalarial activities. J. Med. Chem. 2011, 54, 6624-33. (b) Wencewicz, T. A. New antibiotics from Nature's chemical inventory. Bioorg. Med. Chem. 2016, 24, 6227-6252.

(38) Deopura, B. L. Polyamide fibers. In Polyesters and Polyamides; Deopura, B. L., Alagirusamy, R., Joshi, M., Gupta, B., Eds.; Woodhead Publishing, 2008; pp 41-61. 